\section{HUBUNGAN ANTARA SELF - REGULATED LEARNING DAN \\ PRESTASI AKADEMIK PADA MAHASISWA SEMESTER PERTAMA \\ PRODI PSIKOLOGI \\ UNIVERSITAS PEMBANGUNAN \\ JAYA}

Supriyanto, S.Psi., M.Si.

Program Studi Psikologi,

Universitas Pembangunan Jaya supriyanto@upj.ac.id

\section{Abstrak}

Masa transisi dari jenjang pendidikan menengah (SMA) ke jenjang pendidikan tinggi (universitas) merupakan periode yang krusial bagi mahasiswa baru. Belajar di perguruan tinggi menuntut mahasiswa untuk lebih mandiri, aktif, mengambil keputusan yang tepat dan rasional berkaitan dengan studinya dan mengeksplorasi potensi-potensi yang dimilikinya. Menurut Arjanggi dan Suprihatin (2010), kapasitas regulasi diri (self-regulated learning) memiliki perang penting dalam menentukan kesuksesan pembelajaran mahasiswa di perguruan tinggi. Tujuan penelitian ini adalah untuk melihat hubungan antara self-regulated learning dan prestasi akademik pada mahasiswa semester pertama Prodi Psikologi Universitas Pembangunan Jaya. Hasil penelitian menunjukkan bahwa tidak ada hubungan yang signifikan antara selfregulated learning dan prestasi akademik pada mahasiswa semester pertama Prodi Psikologi Universitas Pembangunan Jaya.
Kata kunci: self-regulated learning, prestasi akademik mahasiswa, pendidikan tinggi

\section{Abstract}

The transition from secondary education (high school) to higher education (university/college) is a crucial period for new students. Studying in the college requires students to be more independent, active, make the right and rational decision regarding to his studies and to explore its potentials. According Arjanggi and Suprihatin (2010), the capacity of selfregulation have a key role in determining the success of student in college. The purpose of this study is to investigate the relationship between self-regulated learning and academic achievement in undergraduate students (freshman) Department of Psychology, Universitas Pembangunan Jaya. The results of this study indicated no significant relationship between self-regulated learning and academic achievement.

Keyword : self-regulated learning, academic achievement, higher education

\section{PENDAHULUAN}

\subsection{Latar Belakang}

Jenjang pendidikan tingkat tinggi (perguruan tinggi) memiliki perbedaan yang sangat 
besar dibandingkan dengan pendidikan tingkat menengah (SMP atau SMA). Perbedaan tersebut dapat meliputi tujuan pembelajaran, metode pembelajaran, sistem administrasi, sistem akademik, materi dan fasilitas pembelajaran, waktu yang dibutuhkan untuk mempelajari suatu bahan ajar sampai mencakup kultur dan suasana pembelajaran. Belajar di perguruan tinggi menuntut mahasiswa untuk lebih mandiri, aktif, bersikap lebih dewasa, mengambil keputusan yang tepat berkaitan dengan studinya dan mengeksplorasi potensi-potensi yang dimilikinya. Sebagai konsekuensi dari perbedaan dan tuntutan-tuntutan tersebut, individu yang memutuskan untuk melanjutkan studinya di jenjang perguruan tinggi diharapkan mampu menyesuaikan diri dengan kehidupan akademis dan kehidupan sosial di kampus serta mempunyai strategistrategi belajar yang efektif bagi dirinya. Menurut Abdullah, Elias, Mahyuddin \& Eli (2009), variabel-variabel yang berkaitan dengan diri mahasiswa, seperti: penyesuaian diri, penyesuaian akademis dan penyesuaian personal-emosional dapat menjadi prediktor yang signifikan dalam memprediksi prestasi akademik mahasiswa tingkat pertama. Pendapat senada diungkapkan oleh Julianti (dalam Melda, 2008) yang menyatakan bahwa kesulitan mahasiswa dalam menyesuaikan diri dengan lingkungan kampus terutama terhadap iklim belajar dapat menghambat prestasi belajar mereka, sebaliknya mahasiswa yang mampu menyesuaikan diri dengan lingkungan kampus terutama terhadap iklim belajar memiliki kemampuan untuk mengikuti proses perkuliahan dengan lancar dan mampu meraih prestasi dengan baik.

Beberapa peneliti telah melakukan studi yang berkaitan dengan masalah-masalah penyesuaian diri mahasiswa baru dengan lingkungan kampusnya. Arjanggi dan Suprihatin (2010) dalam survei awal menemukan bahwa sebagian mahasiswa mengalami kesulitan dalam mengikuti kegiatan belajar di perguruan tinggi. Indikasinya adalah sebagai berikut: 4,2 persen mahasiswa memiliki efikasi diri akademis di bawah rata-rata; 20,8 persen mahasiswa mengalami kecemasan saat menghadapi ujian; 10,4 persen mahasiswa memiliki minat yang kurang terhadap perkuliahan; 6,3 persen mahasiswa mengalami kesulitan terhadap strategi kognitif yang digunakan dalam belajar; dan 20,8 persen mahasiswa mengalami kesulitan regulasi metakognisi dalam belajar. Melalui pendekatan fenomenologis, Fitriana (2014) berhasil mengungkap masalah-masalah penyesuaian diri yang dihadapi oleh mahasiswa baru perempuan yang mengambil jurusan Teknik Nuklir di Universitas Gajah Mada (UGM). Masalahmasalah yang sering dihadapi tersebut diantaranya: adanya beberapa stereotipe dari 
lingkungan sosial terdekat yang tidak mendukung keputusan mereka dalam menempuh studi Teknik Nuklir, serta beban akademik (tugas, ujian, praktikum) yang banyak, berat dan sulit yang harus dihadapi oleh mahasiswa yang bersangkutan. Sementara itu, penelitian Anggani (2010) menemukan bahwa beberapa mahasiswa masih kurang serius dalam mengerjakan tugas yang diberikan oleh dosen dan tidak menyusun jadwal belajar yang rutin dan teratur untuk menyiapkan diri dalam menghadapi ujian.

Dalam menempuh pendidikan di perguruan tinggi, dimana peran mahasiswa dalam proses belajar cenderung lebih mandiri dan aktif, maka kemampuan untuk mengidentifikasi strategi-strategi belajar yang tepat, mengatasi kesulitan dalam proses belajar dan kemampuan meregulasi diri sangat dibutuhkan. Menurut Arjanggi dan Suprihatin (2010), kapasitas regulasi diri (self-regulated learning) memiliki perang penting dalam menentukan kesuksesan pembelajaran mahasiswa di perguruan tinggi. Lebih lanjut, Arjanggi dan Suprihatin (2010) menyatakan bahwa kesulitan strategi kognitif yang digunakan dalam belajar mahasiswa menandakan masih banyak mahasiswa yang belum memahami potensi kognitif yang dimilikinya. Kesulitan dalam regulasi metakognisi menandakan bahwa masih banyak mahasiswa yang belum mampu mengalokasikan waktu belajarnya dan strategi belajarnya secara baik. Pendapat serupa dikemukakan oleh Pratiwi (2009) yang menyebutkan bahwa self-regulated learning merupakan dasar kesuksesan belajar, problem solving, transfer belajar, dan kesuksesan akademis secara umum. Pada intinya self-regulated learning adalah usaha untuk memonitor, meregulasi, dan mengontrol aspek kognisi, motivasi, dan perilaku individu dalam proses belajar.

Untuk meningkatkan kemampuan selfregulated learning, menurut Zimmerman (dalam Anggani 2010) dapat dilakukan dengan cara mengevaluasi dan memonitor sendiri proses belajarnya, menetapkan tujuan belajar dan strategi pencapaiannya, pelaksanaan dan melakukan pemantauan proses belajar, serta melakukan pemantauan hasil dan memperbaiki strategi bila strategi yang diimplementasikan kurang berhasil. Lebih lanjut Zimmerman, Greenberg \& Weinstein (1994) menyatakan sebuah pelatihan atau kursus dapat dilaksanakan untuk membantu individu menjadi seorang pembelajar yang strategis dan efektif. Topiktopik spesifik yang diberikan untuk menjadi pelajar yang efektif: peran goal setting, peran self-management, manajemen perencenaan pembelajaran, time management, kemampuan mendengarkan, mempersiapkan ujian, memanfaatkan umpan balik (feedback) dan kemampuan coping 
stress di lingkungan akademik. Seorang pelajar dapat dikatakan telah melakukan self-regulated learning apabila pelajar tersebut telah mengatur tingkah laku dan kognisinya secara lebih sistematis, memproses dan mengintegrasikan pengetahuan, mengulang informasi untuk diingat, mengembangkan dan mempertahankan belief yang positif tentang kapasitas pembelajaran, serta mampu mengantisipasi hasil (outcome) dari tindakan-tindakan yang telah mereka lakukan (Ajisuksmo, 1996).

\subsection{Rumusan Masalah}

Permasalahan yang hendak diajukan pada penelitian ini yaitu: Apakah ada hubungan antara self-regulated learning dan prestasi akademik mahasiswa semester di Prodi Psikologi Universitas Pembangunan Jaya?

\subsection{Tujuan Penulisan/Penelitian}

Penelitian ini dilakukan untuk mengetahui hubungan antara self-regulated learning dan prestasi akademik mahasiswa semester pertama (Tahun Ajaran 2014/2015) di Prodi Psikologi Universitas Pembangunan Jaya. Selain itu melalui penelitian ini dapat diketahui gambaran kemampuan selfregulated learning yang dimiliki oleh mahasiswa semester pertama (Tahun Ajaran 2014/2015) di Prodi Psikologi Universitas Pembangunan Jaya.
Diharapkan setelah penelitian selesai, akan memberikan manfaat-manfaat praktis dan teoritis. Manfaat teoritis penelitian ini yaitu memberi sumbangan pengetahuan terhadap bidang psikologi pendidikan, khususnya menambah literatur tentang hubungan antara self-regulation learning dan prestasi akademik, mengingat hasil-hasil penelitian sebelumnya mengenai self-regulation learning dan prestasi akademik menunjukkan hasil yang tidak konsisten. Sebagai manfaat praktis, hasil dari penelitian ini dapat menjadi rekomendasi untuk diadakannya pelatihan self-regulation learning khususnya bagi mahasiswa baru atau mahasiswa yang memiliki prestasi akademik rendah.

\section{TINJAUAN TEORITIS DAN PERUMUSAN HIPOTESIS}

\subsection{Prestasi Akademik}

Beberapa ahli sudah mencoba mengartikan prestasi akademik. Winkel (dalam Kurniawati \& Leonardi, 2013) mendefinsisikan prestasi akademik sebagai penampakan hasil belajar seseorang yang merupakan hasil suatu penilaian di bidang pengetahuan, ketrampilan dan sikap sebagai hasil belajar yang dinyatakan dalam bentuk nilai. Sementara itu, Sobur ( dalam Sutera, Sudirman \& Nur, 2014) menyatakan bahwa prestasi akademik merupakan perubahan dalam hal kecakapan tingkah laku ataupun 
kemampuan yang dapat bertambah selama beberapa waktu yang tidak disebabkan proses pertumbuhan, tetapi adanya situasi belajar. Dalam hal ini prestasi akademik dipandang sebagai bukti usaha yang diperoleh mahasiswa. Sedangkan Djamarah (dalam Sitepu, 2014) mengartikan prestasi akademik sebagai suatu hasil yang diperoleh, dimana hasil tersebut berupa kesan-kesan yang mengakibatkan perubahan dalam diri individu sebagai hasil akhir dari aktivitas belajar. Sehingga dapat dikatakan bahwa prestasi akademik merupakan perubahan dalam hal kecakapan tingkah laku, ataupun kemampuan yang dapat bertambah selama beberapa waktu dan tidak disebabkan proses pertumbuhan, tetapi adanya situasi belajar. Dari tiga pengertian di atas, maka dapat disimpulkan bahwa definisi dari prestasi akademik yaitu hasil dari proses belajar yang telah ditempuh oleh siswa dan ditunjukkan dalam bentuk nilai atau angka yang mengindikasikan adanya perubahan kemampuan, kecakapan, keterampilan dan pengetahuan siswa selama menempuh proses belajar.

Prestasi akademik yang diperoleh oleh mahasiswa pada dasarnya merupakan hasil kombinasi dari berbagai faktor yang berbeda. Namun faktor-faktor yang berkontribusi terhadap prestasi akademik dapat dibedakan menjadi dua, yaitu faktor eksternal dan internal (Suryabrata, dalam
Sitepu 2014). Menurut Slameto (dalam Kurniawati \& Leonardi, 2013) salah satu faktor eksternal yang mempengaruhi prestasi akademik yaitu keikutsertaan/partisipasi mahasiswa dalam berbagai kegiatan keorganisasian atau Unit Kegiatan Mahasiswa (UKM) di kampus. Faktor lain yang mempengaruhi prestasi akademik menurut Everson \& Tobias (dalam Kurniawati \& Leonardi, 2013) adalah metakognisi. Salah satu komponen metakognisi yaitu metacognition regulation berhubungan dengan prestasi akademik pada perguruan tinggi dan merupakan prediktor yang baik untuk kesuksesan. Sementara itu menurut pendapat Rola (dalam Oktavia, 2013), terdapat empat faktor yang mempengaruhi prestasi akademik siswa, yaitu:

1. Jenis Kelamin. Prestasi akademik yang tinggi biasanya diidentikkan dengan maskulinitas, sehingga banyak wanita yang belajar tidak maksimal khususnya jika wanita tersebut berada diantara pria. Pada wanita terdapat kecenderungan takut akan kesuksesan, yang artinya pada wanita terdapat kekhawatiran bahwa dirinya akan ditolak oleh masyarakat apabila dirinya memperoleh kesuksesan, namun sampai saat ini konsep tersebut masih diperdebatkan.

2. Keluarga dan budaya. Besarnya kebebasan yang diberikan orang tua kepada 
anaknya, jenis pekerjaan orang tua dan jumlah serta urutan anak dalam keluarga memiliki pengaruh yang sangat besar dalam perkembangan prestasi. Produk-produk kebudayaan pada suatu daerah seperti cerita rakyat, sering mengandung tema prestasi yang bisa meningkatkan semangat.

3. Konsep diri. Konsep diri merupakan bagaimana individu berpikir tentang dirinya sendiri. Apabila individu percaya bahwa dirinya mampu untuk melakukan sesuatu, maka individu akan termotivasi untuk melakukan hal tersebut sehingga berpengaruh dalam tingkah lakunya.

4. Pengakuan prestasi. Individu akan berusaha bekerja keras jika dirinya merasa diperdulikan oleh orang lain. Dimana prestasi sangat dipengaruhi oleh peran orang tua, keluarga dan dukungan lingkungan tempat dimana individu berada. Individu yang diberi dorongan untuk berprestasi akan lebih realistis dalam mencapai tujuannya.

\subsection{Self-Regulated Learning}

Zumbrunn, Tadlock \& Roberts (2011) mendefisikan self-regulated learning sebagai proses yang membantu siswa dalam mengatur pikiran-pikiran, tingkah laku dan emosi mereka dalam rangka mengarahkan pengalaman belajar mereka. Sedangkan menurut Zimmerman (dalam Sitepu, 2014), self-regulated learning merupakan proses dimana seorang peserta didik mengaktifkan dan mendorong kognisi, perilaku dan perasaannya yang secara sistematis berorientasi pada suatu tujuan belajar. Sebagai kesimpulan, definisi self-regulated learning dalam pandangan (Zimmerman, 1990), meliputi tiga aspek: penggunaan strategi-strategi regulasi diri, responsivitas terhadap umpan balik tentang keefektivan proses belajar dan interdependensi proses motivasi.

Salah satu karakteristik siswa yang mempunyai kapasitas self-regulation yaitu mereka mampu mengevaluasi dan menyadari apakah mereka mempunyai fakta dan memiliki kemampuan tertentu atau tidak. Tidak seperti siswa yang pasif, siswa yang mempunyai self-regulation akan secara proaktif mencari informasi ketika mereka membutuhkan dan kemudian akan melakukan langkah selanjutnya agar dapat memahami informasi tersebut. Pada saat menghadapi berbagai hambatan, seperti kondisi belajar yang buruk, guru yang membingungkan dalam mengajar, atau kesulitan memahami buku teks, siswa yang mempunyai keterampilan self-regulation akan mampu mencari jalan keluar agar dapat sukses (Zimmerman, 1990). Zimmerman (dalam Sitepu, 2014) juga menambahkan bahwa individu yang memiliki selfregulated learning merupakan individu yang aktif secara metakognisi, motivasi, dan 
perilaku didalam proses belajarnya. Selfregulated learner adalah individu yang mampu menentukan tujuan dan menggunakan strategi yang tepat untuk mencapai tujuan belajar.

Sebagai suatu proses, self-regulation dapat digambarkan sebagai siklus berputar seperti yang terlihat dalam gambar 1 .

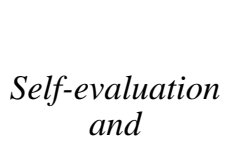

monitoring

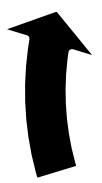

Strategyoutcome monitoring
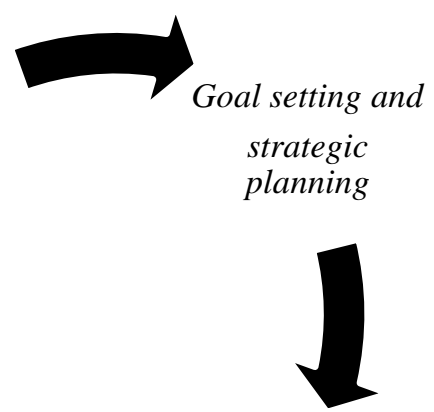

Strategyimplementation monitoring
Gambar 1. Siklus Self-regulated Learning

Zimmerman, Bonner, dan Kovach (dalam Monica, dkk., 2014), menjelaskan empat tahapan siklus self-regulation sebagai berikut:

\section{Self-Evaluation and Monitoring}

Pada tahap ini, pelajar mengevaluasi efektivitas kinerja mereka dalam suatu kegiatan belajar. Keefektivan ini dapat dinilai melalui pengamatan dan pencatatan kinerja sebelumnya dan hasil belajar yang telah diperoleh. Tahap ini melibatkan evaluasi seseorang pada saat belajar atau mengerjakan tugas.

\section{Goal Setting and Strategic Planning}

Pada fase ini, pelajar dituntut untuk menganalisis tugas belajar, menetapkan tujuan belajar tertentu, dan membuat rencana atau memperbaiki strategi untuk mencapai tujuan (goal). Agar goal setting and strategic planning dapat dijalankan dengan optimal, prinsip-prinsip penetapan goal-setting yang disebut sebagai SMART (Specific, Measurable, Achieveble, Realistic, Time-Based) dapat dilakukan pada fase ini.

\section{Strategy-Implementation Monitoring}

Pada tahap ketiga, yaitu tahap Strategyimplementation monitoring, pelajar mencoba melaksanakan strategi belajar dalam konteks yang terstruktur dan memantau keakuratan pengimplementasiannya. Pada tahap ini penerapan pilihan strategi, tergantung pada strategi yang sebelumnya digunakan, umpan balik dari teman sebaya atau guru, dan selfmonitoring.

\section{Strategic-Outcome Monitoring}

Dalam tahap terakhir proses self regulation, pelajar dituntut untuk memantau dan menilai hubungan antara hasil belajar dan keefektivan strategi belajar. Efektivitas strategi pembelajaran tergantung pada sejumlah tugas, konteks belajar, dan faktor- 
faktor personal yang dapat berfluktuasi. Pelajar juga memonitor kemajuan saat mereka mengerjakan tugas secara menyeluruh, mengelola emosi yang mengganggu dan memantau fluktuasi motivasi serta menyesuaikan kembali strategi-strategi belajar yang tepat untuk mendorong kesuksesan.

\subsection{Hubungan Antara Self-Regulated Learning dengan Prestasi Akademik}

Hasil-hasil penelitian sebelumnya menunjukkan hubungan yang tidak konsisten antara self-regulad learning dengan prestasi akademik. Beberapa peneliti menemukan adanya korelasi positif antara self-regulad learning dan prestasi akademik. Namun penelitian lain mendapatkan prestasi akademik tidak berhubungan dengan variabel self-regulad learning. Hurk (dalam Arjanggi \& Suprihatin, 2010) yang melakukan studi tentang belajar berdasar regulasi diri pada mahasiswa S1 Psikologi di Universitas Maastricht menemukan bahwa mahasiswa yang merencanakan waktu lebih baik dan memiliki ketrampilan monitoring diri lebih baik lebih efisien mengalokasikan waktu belajarnya. Mei dan Liyana (dalam Sitepu, 2014) mengemukakan dalam hasil penelitiannya terhadap mahasiswa Fakultas Sains Universitas Sains Malaysia, bahwa salah satu faktor yang mempengaruhi prestasi akademik mahasiswa adalah selfregulated learning. Selain itu, Bell dan Akroyd (dalam Sitepu, 2014) menambahkan bahwa self-regulated learning merupakan bagian dari teori pembelajaran kognitif yang menyatakan bahwa perilaku, motivasi, dan aspek lingkungan belajar akan mempengaruhi prestasi seorang pelajar.

Penelitian yang dilakukan Anggani (2010); Kurniawati \& Leonardi (2013) menunjukkan hasil yang kontradiktif dengan penelitianpenelian di atas. Menurut Anggani (2010), tidak terdapat hubungan antara selfregulated learning dan prestasi akademik. Penelitian yang dilaksanakan oleh Kurniawati \& Leonardi (2013) juga menunjukkan output serupa, tidak ada hubungan antara metakognisi (yang mengandung aspek metacognition regulation) dengan prestasi akademik pada mahasiswa yang aktif dalam organisasi di kampus.

\subsection{Variabel dan Hipotesis Penelitian}

Pada penelitian ini terdapat dua variabel yang akan dianalisis. Variabel pertama yaitu self-regulated learning. Self-regulated learning didefinisikan sebagai proses yang membantu siswa dalam mengatur pikiranpikiran, tingkah laku dan emosi mereka dalam rangka mengarahkan pengalaman belajar mereka (Zumbrunn, Tadlock \& Roberts, 2011). Skor Self-regulated learning 
diperoleh dari skor total kuesioner Selfregulated learning. Variabel kedua adalah prestasi akademik. Winkel (dalam Kurniawati \& Leonardi, 2013) mendefinsisikan prestasi akademik sebagai penampakan hasil belajar seseorang yang merupakan hasil suatu penilaian di bidang pengetahuan, ketrampilan dan sikap sebagai hasil belajar yang dinyatakan dalam bentuk nilai. Skor prestasi akademik diperoleh dari nilai Indeks Prestasi Semester (IPS) mahasiswa semester pertama.

Hipotesis penelitian yang diajukan pada penelitian ini adalah sebagai berikut:

Ha: Ada hubungan yang signifikan antara self-regulated learning dan prestasi akademik pada mahasiswa semester pertama Prodi Psikologi Universitas Pembangunan Jaya

Ho: Tidak ada hubungan yang signifikan antara self-regulated learning dan prestasi akademik pada mahasiswa semester pertama Prodi Psikologi Universitas Pembangunan Jaya

\section{ANALISIS DATA}

Pengambilan data dilaksanakan pada tanggal 17 November 2014. Dari seluruh mahasiswa semester pertama yang terdaftar di Prodi Psikologi Universitas Pembangunan Jaya Tahun Ajaran 2014/2015, mahasiswa yang mengisi dan mengembalikan kuesioner secara lengkap berjumlah 20 orang. Setiap subyek diberikan kuesioner self-regulated learning dan diminta untuk mengisi kuesioner tersebut secara lengkap dan benar. Kuesioner yang tidak diisi lengkap sesuai dengan instruksi, tidak dapat diolah dan tidak akan diproses lebih lanjut.

Setelah proses input dan koding data kuesioner selesai, tahap selanjutnya adalah menganalis data dengan menggunakan program (software) Statistical Package for the Social Science (SPSS). Untuk menjawab permasalahan yang diajukan, peneliti melakukan uji korelasi skor kuesioner selfregulated learning dengan skor prestasi akademik mahasiswa dengan menggunakan teknik korelasi Spearman Product Moment.

Pengujian validitas konstruk skala selfregulated learning menggunakan metode internal consistency dimana skor setiap item dikorelasikan dengan skor totalnya. Jenis korelasi yang digunakan yaitu Pearson Product Moment. Berdasarkan hasil analisis, koefisien validitas item skala ini terentang mulai $0,333-0,633$.

Pengujian reliabilitas untuk kuesioner selfregulated learning menggunakan rumus koefisien Alpha Cronbach, yang memang biasa digunakan untuk mengukur reliabilitas alat tes yang memiliki banyak skor (Anastasi \& Urbina, 1997). Teknik ini dilakukan 
apabila kita ingin melihat homogenitas dari item-item dalam alat ukur. Selain itu, menurut Kaplan \& Sacuzzo (dalam Wardani 2003) teknik Alpha Cronbach biasa dipakai untuk mengukur reliabilitas pada alat ukur yang berbentuk skala sikap dengan alternatif jawaban lebih dari dua. Koefisien reliabilitas skala self-regulated learning sebesar 0,932 yang berarti alat ukur ini reliabel.

Untuk menguji hipotesis penelitian, maka dilakukan uji korelasi antara variabel selfregulated learning dan prestasi akademik. Tabel 1 di bawah menunjukkan indeks korelasi antara self-regulated learning dan prestasi akademik sebesar 0,290 namun korelasi tersebut tidak signifikan. Dengan demikian Ha ditolak dan Ho diterima yang berarti tidak ada hubungan yang signifikan antara self-regulated learning dan prestasi akademik pada mahasiswa semester pertama Prodi Psikologi Universitas Pembangunan Jaya

\begin{tabular}{|ll|l|l|}
\hline & & IPS & SRL \\
\hline IPS & Pearson & 1 & .290 \\
& Correlation \\
& Sig. (2-tailed) & & .215 \\
& N & 20 & 20 \\
SRL & Pearson & .290 & 1 \\
& Correlation \\
& Sig. (2-tailed) & .215 & \\
N & 20 & 20 \\
\hline
\end{tabular}

Tabel 1. Korelasi self-regulated learning dan prestasi akademik

Hasil uji korelasi menunjukkan bahwa hiptesis alternatif (Ha) ditolak, sedangkan hipotesis nol (Ho) diterima yang berarti tidak ada hubungan yang signifikan antara self-regulated learning dan prestasi akademik pada mahasiswa semester pertama Prodi Psikologi Universitas Pembangunan Jaya. Hasil ini memperkuat penelitian sebelumnya yang telah dilakukan oleh Anggani (2010) serta Kurniawati \& Leonardi (2013) yang menyatakan tidak terdapat hubungan antara self-regulated learning dan prestasi akademik. Sementara itu di sisi lain, output dari penelitian ini kontradiktif dengan penelitian-penelitian yang dilakukan oleh Mei dan Liyana (dalam Sitepu, 2014) yang menyatakan bahwa salah satu faktor yang mempengaruhi prestasi akademik mahasiswa adalah kemampuan self-regulated learning serta penelitian dari Weinsten dan Mayer (dalam Anggani 2010) yang menyimpulkan bahwa siswa yang mampu memberdayakan strategi-strategi dalam self-regulated learning, khususnya strategi metakognisi dan kognisi akan memiliki prestasi akademik yang lebih tinggi dibandingkan dengan siswa yang tidak mampu memberdayakan strategi selfregulated learning. 


\section{KESIMPULAN}

\subsection{Kesimpulan}

Berdasarkan analis data maka hasil penelitian ini menyimpulkan bahwa tidak ada hubungan yang signifikan antara selfregulated learning dan prestasi akademik pada mahasiswa semester pertama (Tahun Ajaran 2014/2015) Prodi Psikologi Universitas Pembangunan Jaya.

\subsection{Diskusi}

Tidak signifikannya korelasi antara selfregulated learning dan prestasi akademik mahasiswa pada penelitian ini dapat dijelaskan melalui dua pendekatan, yaitu pendekatan teoritis dan metodologis. Perbedaan individual dapat menentukan perbedaan kapasitas self-regulated learning antara satu siswa dengan siswa yang lain. Menurut Ajisuksmo (1996), dapat dimungkinkan individu yang berbeda menggunakan strategi-strategi belajar yang berbeda ketika menghadapi situasi yang sama. Namun bisa juga satu individu akan menggunakan strategi yang berbeda pada saat berada dalam situasi yang berbeda. Persepsi atau pandangan siswa terhadap apa yang dipelajari merupakan komponen penting dari self-regulated learning (Morton, Thorkildsen \& Nicholls, dalam Ajisuksmo 1996). Apa pun yang dilakukan siswa dalam proses belajar dan bagaimana mereka meregulasi segala kegiatan belajarnya akan dipengaruhi oleh pandangan seberapa penting pelajaran tersebut bagi mereka. Setiap siswa mempunyai pandangan atau konsepsi yang berbeda terhadap proses belajar dan akan menggunakan konsepsi ini dalam bentuk-bentuk yang berbeda. Aspek lain yang mempengaruhi perbedaan antar individu pada kapasitas self-regulated learning yaitu perbedaan budaya. Dalam pandangan Ajisuksmo (1996), perbedaan individual dalam kemampuan metakognisi dapat dijelaskan melalui interaksi antar manusia dan sosial serta konteks budaya atau circumtances dimana interaksi itu terjadi. Bagaimana individu belajar untuk berpikir dan menyelesaikan masalah dalam kehidupan sehari-hari akan dipengaruhi oleh adaptasi mereka terhadap nilai-nilai, beliefs, praktik/kebiasaan yang berkembang dalam lingkungan sosial dan budaya mereka (Best \& Ruther, dalam Ajisuksmo 1996). Lebih lanjut penelitian yang dilakukan oleh Kontos (dalam Ajisuksmo 1996) menyimpulkan bahwa cara orang tua dalam mengarahkan anaknya dalam memecahkan suatu masalah akan menentukan bagaiamana anak tersebut belajar menggunakan self-regulated learning.

Selain adanya perbedaan individual, tidak signifikannya korelasi antara self-regulated learning dan prestasi akademik mahasiswa mungkin juga dikarenakan oleh banyaknya 
faktor yang mempengaruhi skor/nilai prestasi akademik itu sendiri, bukan hanya ditentukan oleh kemampuan self-regulated learning. Menurut Suryabrata (dalam Sitepu, 2014) faktor-faktor yang mempengaruhi prestasi akademik mahasiswa, yaitu:

1. Faktor eksternal, merupakan faktor yang berasal dari luar individu yang meliputi: faktor non sosial, seperti: keadaan udara, suhu udara, cuaca, waktu, tempat, alat-alat yang dipakai untuk belajar. Faktor non sosial ini secara langsung dapat mempengaruhi psikologis seseorang yang berakibat pada hasil prestasi yang akan didapat pada mahasiswa. Sedangkan faktor sosial adalah faktor manusia (sesama manusia), baik manusia itu ada (hadir) maupun tidak hadir secara langsung.

2. Faktor internal merupakan faktor yang berasal dari dalam diri individu, dimana meliputi: faktor fisiologis yaitu keadaan jasmani yang melatarbelakangi aktivitas belajar. Bila keadaan jasmani sehat akan memberikan pengaruh positif dalam proses belajar seseorang sehingga proses belajar tersebut akan memberikan hasil yang optimal. Sedangkan faktor psikologis meliputi minat, bakat, intelegensi, kepribadian dan motivasi peserta didik.

Dari sisi metodologis, tidak signifikannya korelasi antara self-regulated learning dan prestasi akademik mahasiswa dapat disebabkan oleh kurang akuratnya alat ukur (kuesioner) yang digunakan serta sedikitnya jumlah subyek penelitian. Pada penelitian ini, untuk menguji validitas dan reliabilitas kuesioner self-regulated learning digunakan metode internal consistency dan Alpha Cronbach. Agar mendapatkan indeks validitas dan reliabilitas yang lebih valid dan reliable, perlu dikombinasikan dengan menggunakan metode-motode yang lain. Jumlah subyek yang sedikit (20) mungkin juga mempengaruhi hasil korelasi, sehingga jumlah subyek tidak menggambarkan kondisi populasi yang sebenarnya.

\subsection{Saran}

Untuk mendapatkan hasil penelitian lanjutan yang lebih maksimal, berikut ini saran-saran yang bisa dilakukan:

1. Memperbanyak subyek penelitian.

2. Mengurangi perbedaan individual subyek penelitian agar lebih homogen.

3. Menguji coba kuesioner kepada subyek yang lebih banyak sebelum pengambilan data yang sebenarnya dilakukan.

4. Menguji validitas dan reliabilitas kuesioner dengan metode-metode yang lain.

5. Mengkombinasikan pendekatan penelitian dengan pendekatan kualitatif untuk melihat gambaran proses selfregulated learning. 


\section{Daftar Pustaka}

1. Abdullah, M. C., Elias, H., Mahyuddin, R. \& Uli, J. 2009. Adjustment amongs the first year students in a malaysian university. European Journal of Social Sciences, Vol. 8 No. 3, pp. 496-505.

2. Ajisuksmo, C. R.P. 1996. Self Regulated Learning in Indonesia Higher Education. Jakarta: Atmajaya Research Center.

3. Anastasi, A. \& Urbina, S. 1997. Psychological Testing. $\left(^{\text {th }}\right.$ ed.). New Jersey: Prentice-Hall.

4. Anggani, D.M. 2010. Hubungan Antara Self-Regulated Learning dengan Prestasi Akademik. Skripsi: Fakultas Psikologi Universitas Katolik Soegijapranata, Semarang.

5. Arjanggi, R. \& Suprihatin, T. 2010. Metode pembelajaran tutor teman sebaya meningkatkan hasil belajar berdasar regulasi-diri. Makara, Sosial Humaniora, Vol. 14, No. 2, Desember 2010: 91-97.

6. Fitriana, Q.A. 2014. Studi Fenomenologi Penyesuaian Diri Mahasiswa Baru Perempuan Pada Program Studi Teknik Nuklir Universitas Gadjah Mada. Magister Profesi Psikologi Klinis Universitas Gadjah Mada.

7. Kurniawati, R. \& Leonardi, T. 2013. Hubungan antara metakognisi dengan prestasi akademik pada mahasiswa fakultas psikologi universitas airlangga yang aktif berorganisasi di organisasi mahasiswa tingkat fakultas. Jurnal Psikologi Pendidikan dan Perkembangan: 01 Vol. 2, No. 01, April 2013.

8. Melda, S. 2008. Hubungan Antara Konsep Diri Dan Penyesuaian Diri Dengan Prestasi Belajar Pada Mahasiswa Baru Fakultas Psikologi Universitas Sumatera Utara. Skripsi: Fakultas Psikologi Universitas Sumatera Utara, Medan.

9. Oktavia, L.F. 201. Hubungan Prestasi Akademik, Keterampilan Psikomotor Dan Kematangan Emosi Mahasiswa Profesi Ners Unsoed Terhadap Kemampuan Merawat Klien Gangguan Jiwa. Skripsi: Fakultas Kedokteran Dan Ilmu-Ilmu Kesehatan, Jurusan Keperawatan Universitas Jenderal Soedirman, Purwokerto.

10. Pratiwi, A. P. 2009. Hubungan Antara Kecemasan Akademis DenganSelfRegulated Learning Pada Siswa Rintisan Sekolah Bertaraf Internasional Di Sma Negeri 3 Surakarta. Skripsi: Fakultas Psikologi Universitas Diponegoro, Semarang. 